\title{
The Effects of Learning Orientation and Marketing Programme Planning on Export Performance: The Paradoxical Moderating Role of Psychic Distance
}

\begin{abstract}
Despite extensive research on the effect of organisational learning processes on firm performance, how and when a propensity to learn drives export performance of small and medium-sized enterprises (SMEs) remains unclear. Using multiple-informant and time-lagged primary data from 242 SMEs in a sub-Saharan African market, this study examines the roles of marketing programme planning and host country psychic distance in linking export learning orientation to export performance. Findings from the study show that increases in both export learning orientation and marketing programme planning are associated with increases in export performance. Additionally, the study finds that while increases in psychic distance weaken the effect of export learning orientation on export performance, it strengthens the effect of marketing programme planning on export performance. These findings draw attention to the idea that cognitive distance between home and host country markets may play a paradoxical role in explaining when organisational learning activities may help or hurt exporting SMEs.
\end{abstract}

\section{Keywords}

Export learning orientation, psychic distance, marketing programme planning, export performance, paradox 


\section{Introduction}

Exporting activity is of great importance to firms as it helps enhance firms' market position and survival (Morgan et al., 2012; Leonidou et al., 2010). In particular, small and medium-sized enterprises (SMEs) in developing economies can leverage exporting as a springboard to transcend the limits of their home markets and utilise foreign market opportunities (Tasavori et al., 2018; Boso et al., 2016). Nonetheless, given the increasing competitiveness of the international marketplace, understanding the key determinants of export performance is of great concern for both managers and policy makers (Morgan et al., 2004). This effort to understand export performance drivers has enabled exporting research to examine export market knowledge resource bases that enable exporting firms to use internal routines and processes to build learning capabilities to drive export performance (Morgan et al., 2012; Chabowski et al., 2018).

The role of strategic orientations and marketing activities in driving the performance of exporting firms has received substantial scholarly attention (Boso et al., 2018b; Murray et al., 2011; Kuivalainen et al., 2007). On the one hand, extant research has indicated that exporting is a complex business operation that requires distinct export-market related strategic orientations (Cadogan et al., 2016; Zhang et al., 2012) and capabilities (Zou et al., 2003; Morgan et al., 2018). This challenge is even greater for less experienced and resource-constrained exporting SMEs from emerging markets whose strategic orientations to foreign market operations continue to evolve and yet remain poorly understood (O'Grady and Lane, 1996; Zaheer and Hernandez, 2011; Charoensukmongkol, 2016). On the other hand, the strategic management literature suggests that a firm's ability to learn and apply new knowledge in the conduct of organisational activities is an important driver of its strategic actions and performance (Tse et al., 2017). Despite its growing relevance, scholarly knowledge on how and when export learning orientations drive export performance of SMEs remains fragmented and patchy. While extant research has examined how specific organisational learning activities drive export performance (Skarmeas et al., 2016; Gnizy et al., 2017), these studies leave unanswered the question 
of how exporting firms in developing countries may benefit from the deployment of export learning orientations and marketing capabilities (Ellis et al., 2011; Boso et al., 2017).

In particular, the knowledge on the mediating mechanisms that translate emerging market SMEs' learning orientation into export performance outcomes and on boundary conditions that shape the nature of these linkages, remains underdeveloped. Nonetheless, as a strategic disposition, export learning requires specific activity-based mechanisms to convey its influence on export performance. Likewise, the linkage between emerging market SMEs' export learning orientation and export performance is unlikely to be universal and immune to external contingencies, given the potential variations in cultural values and business paradigms across home and foreign markets (Child et al., 2002). In a world where businesses and, in particular, SMEs from developing economies, face unprecedented levels of complexity and volatility that create export learning challenges and subdue seemingly clear-cut solutions (Cavusgil and Cavusgil, 2012; Matanda et al., 2016), understanding how and when SMEs convert their learning orientation into export performance is imperative.

This study contributes to SMEs research in three ways. First, we respond to on-going calls for additional research on SME internationalisation from developing markets (Chabowski et al., 2018; Boso et al., 2018a) and the mechanisms through which export learning drives export performance (Theodosiou and Katsikea, 2013). We draw insights from resource-based theory to conceptualise export learning as a firm resource that can influence export market performance when channelled through marketing programme planning. We contend that the ability to learn about the nuances, opportunities, and challenges in export markets is a primary and fundamental activity for SMEs, as it enables exporting firms to develop knowledge about opportunities and risks in targeted export markets, as well as design and formulate marketing programme strategies to exploit new export market opportunities (Morgan et al., 2012).

Second, we examine the potential paradoxical role of perceived psychic distance (O'Grady and Lane, 1996; Sousa and Bradley, 2006) to understand the conditions under which the effect of export learning on export performance via export marketing programme planning is more or less beneficial. 
Greater perceived psychic distance may weaken the economic benefits that firms obtain from export learning (Brock et al., 2011; Taylor and Jack, 2013), as it impairs information flows between a firm and its export market in terms of accuracy of information on export market needs and demands (Evans et al., 2000). Paradoxically, a greater perceived psychic distance may prompt firms to formally plan for their export marketing programmes to boost performance. This study argues, therefore, that a greater understanding of the interplay between export marketing programme planning and perceived psychic distance may help to explain how and when export learning influences export performance.

Third, research on export learning, marketing programme planning, and psychic distance has been based on data from Western industrialised economy firms with limited evidence coming from firms in less developed economies (Child et al., 2002; Naldi and Davidsson, 2014; Villar et al., 2014). We extend prior studies further by testing our conceptual model (see Figure 1) in a less studied subSaharan African context: exporting SMEs in Nigeria. Accordingly, our study helps uncover new insights from an exotic context to explain how developing economy SMEs deploy marketing programme planning to channel export market learning activities to export performance, amid varying levels of psychic distance across different export markets.

\section{[Insert Figure 1]}

\section{Theoretical background and hypotheses development}

\section{Learning orientation}

Strategic orientations are fundamental drivers of managerial decision-making and action (Hakala, 2011). They connote an enduring course of thought, disposition, or interest that determine managerial attitudes (Hakala, 2011; Rauch et al., 2009). Research on resource-based theory and the literature on organisational learning reveal that through investment in technology and learning, firms expand their knowledge and capability bases and improve their ability to integrate and utilise information in local and global markets (Schilling, 2002). Thus, learning orientation as a relevant strategic orientation can serve as a critical resource for firms' strategy development (Chung et al., 2015). 
Learning orientation refers to the mind-set and propensity of a firm to create and use knowledge for the purposes of strategy development (Sinkula et al., 1997; Calantone et al., 2002). Learning orientation influences where learning occurs and the nature of what is learned. It defines how firms obtain, share and utilise knowledge (Real et al., 2014). Four commonly accepted elements of learning orientation include a commitment to learning, shared vision, open-mindedness, and intra-organisational knowledge sharing (Calantone et al., 2002; Sinkula et al., 1997). It is, therefore, reflected in the intrinsic motivation to seek, question, and absorb new information. It plays a pivotal role in shaping market information processing (Baker and Sinkula, 1999). Learning orientation, therefore, affects a firm's propensity to value learning as a strategic resource (Baker and Sinkula, 1999), and supports a continuous re-examination of the organisational practices and norms that guide marketing activities (Sinkula et al., 1997). Thus, it constitutes the foundational resource for market information utilisation (Calantone et al., 2002).

Given its strategic importance, the extent to which learning orientation influences organisational performance has been subject to extensive scrutiny by management and marketing researchers (Baker and Sinkula, 1999; Real et al., 2014; Wang, 2008; Calantone et al., 2002). A firm with strong learning orientation is not merely a depository of knowledge but also a knowledge processor, as it shapes firms' likelihood of promoting generative learning as an enduring primary competence (Baker and Sinkula, 1999). Firms' commitment to learning and receptivity to new, external information are fundamental to performance (Wang, 2008). Firms that have enhanced learning orientation are more eager to question longheld assumptions about their central business philosophies, and thus are more likely to adapt to external demands that are seen as a keystone of long-term performance (Baker and Sinkula, 1999).

Extant research on the link between learning orientation and performance suggests that the relationship is more complex than previously assumed (Kropp et al., 2006). Importantly, empirical findings on the relationship remain inconclusive (see Table 1). Specifically, while some prior studies show that a firm's proclivity to learn is positively associated with performance (Real et al., 2014; Wang, 2008), others show a negative association (Ho and Wang, 2015). Yet, other studies provide evidence to show that learning orientation is not directly associated with organisational performance (Chung et al., 2015). Given 
this equivocality of the learning orientation - performance relationship, some researchers have called for additional research on the relationship. For example, Real et al. (2014) suggest that the extent to which learning orientation influences performance is conditional upon it being channelled through organisational routines and processes. Similarly, Calantone et al. (2002) propose additional research to examine organisational mechanisms that may connect learning orientation to organisational performance (see also Sinkula et al., 1997).

Additionally, researchers have also called for further research to understand the conditions under which learning orientation is more or less beneficial to firms (Suliyanto and Rahab, 2012). Calantone et al. (2002), in particular, take a national cultural perspective to argue that knowledge on learning orientation may be enhanced under conditions of varying cultural settings beyond the often researched industrialised markets in North America and Western Europe. Along this line, Baker and Sinkula (1999) suggest that the learning orientation - performance relationship should be examined in market environments that are traditionally noted for instability and turbulence. Furthermore, the complexity of the learning orientation performance relationship is exacerbated when it is considered in an international business context. This contextual complexity has the potential to convolute findings and hinder the applicability of research implications.

\section{[Insert Table 1]}

Thus, in following the suggestion by Katsikeas et al. (2016), this study focuses on a specific form of export-related learning orientation and a specific export performance outcome. Similarly, learning orientation is a dispositional (or attitudinal) concept (Sinkula et al., 1997; Calantone et al., 2002), and its actual influence on performance outcomes, without accounting for the intervening role of relevant behavioural activities, may limit knowledge development. To this end, we concentrate on a specific marketing behavioural activity (i.e., marketing programme planning) to probe into how this activity helps firms convert export learning orientation into export performance. 
Export learning orientation is a specific form of organisational learning that concentrates on learning about opportunities and challenges in a firm's export environment, as well as the internal processes needed to succeed in export activities. Because foreign markets are more unfamiliar and complex than home markets (Sousa and Bradley, 2006; Evans and Mavondo, 2002), learning about the realities of export markets becomes ever more necessary for creating value and realising export marketing strategies. Firms that maintain learning orientation are more likely to stay alert to external information sources, cognisant of fluid export market demand, and acquire the necessary knowledge to create value (Wang, 2008). In line with the resource-based view of learning orientation (Schilling, 2002), export learning enables organisational knowledge management activities and intra-organisational knowledge sharing (Calantone et al., 2002) to decode and disseminate intricate export market intelligence. Accordingly, as a potentially influential force in firms' international marketing strategies (Baker and Sinkula, 1999; Morgan et al., 2012), export learning orientation can underlie export market learning activities and internalisation of export market knowledge thereby paving the way for increased export performance. Accordingly, we propose that:

\section{Hypothesis 1: Export learning orientation is positively related to export performance}

Though influential, learning orientation is merely a dispositional force that triggers a particular line of thought and strategic direction for firms (Hakala, 2011). It represents a central cultural value system that a firm may hold and seek to follow in the execution of its strategic goals and visions (Real et al., 2014). Thus, learning orientation needs to be realised through organisational processes and routines (Real et al., 2014). One such process is marketing programme planning, which refers to "the on-going managerial process of assessing internal marketing competencies and external environmental trends, segmenting the marketplace, and then formally configuring, efficiently implementing, and systematically evaluating marketing mix strategies with the goal of achieving organisational objectives" (Conant and White, 1999: p. 528). It is a systematic process underpinning the capabilities of a firm to design and implement specific marketing strategies to meet its marketing objectives (Morgan et al., 2012). It provides a comprehensive blueprint for activities that help shape and organise marketing procedures in a firm. It is, therefore, 
inextricably intertwined with market learning through reciprocal and dynamic processes and could be an essential mediating process linking export learning orientation to export performance.

On the one hand, learning orientation can influence a firm's ability to create and use market knowledge (Real et al., 2014), implying that export learning orientation is instrumental to the enactment of marketing plans to serve export market needs. In particular, export learning orientation can stimulate export marketing strategy development by providing rich information on export market demands and trends (Conant and White, 1999). We therefore argue that export learning orientation can be a significant driving force behind the design and implementation of marketing programme plans for export markets. On the other hand, despite increasing turbulence and uncertainty in the global business environment (Putnam et al., 2016; Cavusgil and Cavusgil, 2012), marketing planning remains an essential element in the smooth execution of business operations. In particular, marketing programme planning can help firms set realistic goals, gauge their competences, and execute marketing activities in foreign markets (Conant and White, 1999).

Planning becomes especially relevant for complex business operations with ambiguous inputs and outputs (Alpkan et al., 2007; Oliva and Watson, 2011). A well-prepared strategic marketing plan may alleviate internal and external uncertainties by clearly defining a firm's marketing strengths and weaknesses with respect to marketing plans compared to export market competitors' plans (Alpkan et al., 2007). Therefore, strategic planning approaches has been suggested as critical factors in business performance (Lysonski and Pecotich, 1992), although there exists an alternative line of research that suggests rigid marketing planning processes could damage performance in dynamic environments (Slotegraaf and Dickson, 2004). Drawing on this line of research, we argue that market programme planning can, at an overall level, serve as an enabler of the performance of firms' export operations. Additionally, market programme planning can function as a procedural conduit channelling a firm's cultural values, prioritising and driving learning into increased export market performance. Recent research suggests that learning might not directly improve performance. Instead, it must be channelled through appropriate processes and mechanisms within the control of the organisation (Suliyanto and Rahab, 2012). 
Marketing programme planning is a key process that turns organisational learning propensity into increased export performance by enabling firms to convert their learning values and orientations into actionable marketing plans (Cavusgil and Cavusgil, 2012). Thus, we argue that:

Hypothesis 2: (A) Export learning orientation is positively related to marketing programme planning, (B) marketing programme planning is positively related to export performance; and therefore $(C)$ marketing programme planning mediates the relationship between export learning orientation and export performance

The paradoxical role of psychic distance

Beyond the processes through which export learning orientation influences export performance, the effect may also be dependent upon export market environment conditions within which learning activities are executed. One central concept often used to understand a firm's export market environment condition is psychic distance (Sousa and Bradley, 2006; O'Grady and Lane, 1996). It refers to the psychological distance between a firm's home and foreign markets with regard to cultural and business practice differences (Evans and Mavondo, 2002). Psychic distance is a consequence of a number of inter-related factors, of which perception is a major element (Evans and Mavondo, 2002). These factors curb information flow between home and host country operations, including culture, language, business practices, political and legal systems, education, economic development, marketing infrastructure, and industry structure (Evans et al., 2000). Such a portfolio of differences between home and host markets can impose ambiguous and multidimensional influences on firms' international business activities (O'Grady and Lane, 1996).

This study specifically focuses on psychic distance instead of another undoubtedly related concept of institutional distance (Håkanson and Ambos, 2010). Whereas institutional distance is concerned with differences between two given countries in terms of regulative (state rules and regulations), normative (legitimacy of business deeds), and cognitive (beliefs and value system) differences (Gaur and Lu, 2007), 
psychic distance focuses on perceptual variations in economic, language, cultural, educational, and business practices between a firm's home and host market environments (Dow and Karunaratna, 2006). Psychic distance, therefore, comprehensively captures managers' overall perception of the host market visà-vis home market business environment conditions (Sousa and Lages, 2011). Thus, while some degree of similarities may be expected, psychic distance is a more comprehensive concept than institutional distance, and is more relevant to this study in that it raises an important question about how managerial perceptions of variation in home and host market practices shapes the effectiveness of strategic decisions.

As the focus of organisations is the management of known and knowable parameters (Carson et al., 2006), psychic distance challenges management practice in a fundamental way by introducing unknown parameters into the equation, stemming from the complexity and unfamiliarity of operating in foreign markets (Sousa and Bradley, 2006). As firms venture into export markets, the inputs and outputs of their managerial decision making and activities become blurred, and the influence of psychic distance on performance can be either positive or negative (Evans et al., 2000; Stöttinger and Schlegelmilch, 1998). Such a challenge can put managers in a cognitively difficult position and undermine firm functioning. However, as the influence of psychic distance on firm functioning is likely to be relative to that of competitors in foreign markets, firms that can handle psychic distance better in relative terms can be in an advantageous position. Such dynamics around this construct highlight the paradoxical role of psychic distance (O'Grady and Lane, 1996; Zaheer and Hernandez, 2011; Evans and Mavondo, 2002).

Paradox theory provides insights into the nature and management of contradictory internal and external demands to explain a broad range of business phenomena that take place in increasingly volatile and rapidly changing environments (Putnam et al., 2016; Schad et al., 2016). Paradox is the dynamic and persistent tensions of juxtaposed opposites and contradictions that are developed as part of actions and interactions (Lado et al., 2006). Paradoxes "impose and reflect back on each other, and develop into seemingly irrational or absurd situations because their continuity creates situations in which options appear mutually exclusive, making choices among them difficult" (Putnam et al., 2016: p.72). There has been a growing body of literature on organisational paradox (Leonard, 1992; Smith and Lewis, 2011; Putnam et 
al., 2016) and its linkages with issues such as innovation (Jay, 2013) and learning (Ho and Wang, 2015). Paradox has also recently found applications in marketing, particularly with respect to interorganisational competition (Mattsson and Tidström, 2015) as well as in small business management (Ortega-Argilés et al., 2009; Volery et al., 2015). The application of paradox theory has helped to disentangle complex phenomena like psychic distance and grasp their nature and influences in a more realistic way (Putnam et al., 2016).

Within the context of exporting, paradox often arises from the competing demands of institutional environments (Smith and Tracey, 2016). It often invokes inevitable yet rewarding challenges for organising: difficult to face and manage but rewarding once it is embraced and dexterously navigated. Psychic distance is mostly determined by cultural distance and the individual values of the managers (Sousa and Bradley, 2006). Hence, the paradox of psychic distance mainly stems from the complex interplay between the external determinants of distance such as geography and culture, and managerial perception. On the one hand, psychic distance is a daunting challenge when operating in murky waters due to information and learning related obstacles. On the other hand, it may present unexpected opportunities potentially stemming from unanticipated events and the failure of competitors to handle the challenges it presents. The mixture of objective external forces and one's perception of these forces, makes the influence of physics distance less predictable and paradoxical (Evans and Mavondo, 2002). Thus, the psychic distance paradox, which denotes a dual or dilemmatic influence of psychic distance on a firm's orientations and marketing strategy outcomes, represents a significant managerial conundrum that requires additional scholarly attention. This study, therefore, focuses on exposing the paradoxical moderating role of psychic distance in the relationships between export learning orientation, marketing programme planning, and export performance.

We argue that firms with higher degrees of export learning orientation exhibit a higher degree of willingness and motivation to acquire new market information, turn such information into new insights, and leverage such insights to their advantage. However, given that learning orientation is more of an attitudinal concept than is a behaviour, the relationship between export learning orientation and export 
performance is likely to be shaped by a variety of perceptual contingent factors. One such perceptual factor is perceived psychic distance (Stöttinger and Schlegelmilch, 1998; Johnston et al., 2012).

Psychic distance is often understood in terms of perceived barriers to learning about foreign markets (Evans and Mavondo, 2002). Hence, as psychic distance increases, export marketing activities often face several difficulties, partly due to a lack of a shared frame of reference and understanding about perceived differences between home and host market actors (Johnston et al., 2012). For example, differences in perception may emerge between home country and respective host country trading partners concerning the benefit of learning philosophies. Thus, psychic distance can create learning bottlenecks and inhibit the realisation of a tendency for learning about foreign markets and its potential influence on the effectiveness of export activities (Evans and Mavondo, 2002). Additionally, exporting firms can find it cognitively difficult to comprehend unfamiliar and perceptually distant market needs and challenges. For example, a greater perceived socio-cultural distance can impede managers' ability to understand the sociocultural implications of serving in a host market. Under such circumstances, firms may find it daunting to translate their export learning into increased performance. Therefore, we argue that increases in psychic distance can weaken the export performance benefits of export learning orientation.

Hypothesis 3A: The relationship between export learning orientation and export performance is weakened when perceived psychic distance increases in magnitude.

Psychic distance can provide firms with subtle advantages embedded in its often more apparent hindrances (O'Grady and Lane, 1996; Zaheer and Hernandez, 2011). We argue that a potentially positive side of the paradoxical influence of psychic distance materialises to those firms that can discover and leverage its flip-side benefits. The central benefit of marketing programme planning in linking export learning to performance is its role in aiding firms to realise and apply learning orientation in export markets. We suggest that firms that craft and execute marketing programmes can achieve export performance better in foreign markets with high psychic distance. 
We propose that systematic and cognisant marketing programme planning and execution can help firms tease out subtle advantages of psychic distance and supplant its negative effects. Exporters who design and implement export marketing programme plans often have a clear sense of key competencies in the export market environment (Conant and White, 1999). The negative role of psychic distance can thus turn positive once the distance is bridged by juxtaposing the firm's marketing competences against the export market environment and properly configuring and efficiently implementing export marketing strategies (Morgan et al., 2012). Firms that realise their marketing planning programme in export markets with high psychic distance can pave the way for greater export performance when they play to their strengths and turn market challenges into an asset through conscientious marketing planning activities (Lysonski and Pecotich, 1992).

When linked with export learning orientation, market programme planning can unlock opportunities hidden in the obscurity of distant markets. As planning is often a pivotal tool in handling unfamiliarity in new contexts (Lysonski and Pecotich, 1992), marketing programme planning helps firms evaluate uncertainties and potential unknown possibilities in export markets. Thus, we posit that the effect of marketing programme planning on export performance is strengthened when perceived psychic distance increases because, in such circumstances, firms may have planned for their foreign markets with high psychic distance by collecting and analysing intelligence on those markets. Such that, as marketing programmes become well planned through stronger orientation to export learning, and as perceived psychic distance increases, there is a greater likelihood that firms will transcend perceived market uncertainties and utilise opportunities, leading to boost performance in export markets. Accordingly, we propose that:

Hypothesis 3B: The indirect effect of export learning orientation, via marketing programme planning, on export performance is strengthened when perceived psychic distance increases in magnitude.

\section{Research Method}

Research Context and Data collection 
We tested our hypotheses among exporting firms in a sub-Saharan African economy - Nigeria. Two main reasons informed the choice of Nigeria for our empirical setting. First, Nigeria has emerged as one of the two largest economies in sub-Saharan Africa with a projected gross domestic product (GDP) of US\$1.12 trillion at purchasing power parity rates, and the most populous with an estimated 190 million population in 2016 (CIA World Factbook, 2018). As a result, Nigeria has become a significant player in global business activities. Second, Nigeria operates an open market economy that has led to an increased presence of privately-owned SMEs with significant exporting operations. The fast growth of the key non-oil sectors (e.g., agro-processing and information and communication technology) in Nigeria has generated significant interest in the exporting firms operating in this country (Ibeh et al., 2012).

The study involved a multi-industry survey of exporting firms. Prior to the main survey launch, we pre-tested the survey instrument among several academics with research expertise in international business and export marketing, to evaluate face validity and the appropriateness of the scales used in the survey. The Nigerian business directory was subsequently used as a sampling frame. This directory provides information on firms' managerial profile and contact details. We randomly selected 1,000 exporting companies that met our selection criteria. Considering the inaccuracy and scarcity that may be associated with databases from developing economies (Khavul et al., 2010), the firms were contacted by telephone to (1) evaluate their eligibility for the study, (2) verify their contact details, (3) find key informants. Overall, 790 firms agreed to participate in the study. Given the unreliable postal system in Nigeria, we followed literature recommendations (e.g., Acquaah, 2012) to use a face-to-face survey instrument administration procedure. Accordingly, we hired a local research consultancy firm with highly trained and experienced field researchers to administer the survey instruments under the supervision of an experienced export marketing researcher associated with this study.

Subsequently, two studies were undertaken. In study one, senior managers (i.e., chief executive officers, export managers, international business development managers, export sales directors) of 
the 790 firms were contacted for information on the firms' export learning, marketing programme planning and perceived psychic distance. A total of 261 responses was obtained. We eliminated 19 responses as a result of extensive missing data (see Morgan et al., 2012) leaving 242 valid responses, representing a $31 \%$ response rate. In study two (i.e., one year after study one), we contacted the finance managers (i.e., finance officers and/or chief accountants) of the 242 firms to obtain the export performance data. Our use of multiple informants and multiple time points helped rule out potential common methods bias concerns and minimise single informant bias in the study. In sum, the study relies on data from two sources (i.e., data from export managers on the independent, mediator and moderator variables and data from finance directors on the dependent variable). Sample characteristics of the participant firms are summarised in Table 2.

\section{[Insert Table 2]}

\section{Measures}

Export performance was measured by an adapted version of the export performance measure developed by Morgan et al. (2004) and used by Hult et al. (2008). The scale contains five items that capture senior finance directors' satisfaction (in time two) with export cash flow, export sales growth, export profitability, return on assets, and profit margin growth from export operations. We validated these perceptual measures with objective measures (e.g., export sales growth and export sales volume). The correlation between the objective and perceptual performance measures was very high $(r=.91, p<.01)$. Export learning orientation was operationalised by borrowing items from more culturally based measures from Baker and Sinkula (1999) and Gnizy et al. (2014). Marketing programme planning was measured with a scale from Conant and White (1999). The scale captured the extent to which the firms follow internal processes to assess internal competencies and external environmental trends to implement marketing strategies efficiently. Psychic distance was captured on a five-item scale adapted from prior research (Murray et al., 2011; Sousa and Lages, 2011). The scale tapped managers' perception of a difference between the firms' home and host country markets. 
In all cases, we used seven-point scale items to capture the perceptual measures. Seven-point scale items are often deemed appropriate for measuring attitudes, beliefs, and opinions due their capacity to increase item reliability (DeVellis, 2011; Allen and Seaman, 2007). In particular, sevenpoint scale items allow respondents to more precisely describe their beliefs and lessen restriction of ranges (Tobacyk, 2004), and thus, allows for longer tails and more skewness than a five-point interval (De Winter and Dodou, 2010).

We controlled for two variables that previous research shows can affect export performance: firm size, measured by number of employees (logarithm transformed); and international experience, measured by number of years the firms have been exporting (logarithm transformed).

\section{Bias Assessment}

In addition to using procedural measures to minimise biases in the data, we followed statistical processes to further assess the threat posed by two biases: non-response bias and common method bias. First, we assessed non-response bias by comparing early and late respondents using annual sales, export sales, scope of exporting and number of full-time employees. No significant differences were found. Second, a comparison of the 242 responses and 46 randomly selected non-participant firms, revealed no significant differences in the means of annual sales and firm size between the two groups. Thirdly, we followed recommended ex-ante procedural remedies (Podsakoff et al., 2012) to minimise the threat of method bias by using multiple data sources and time-lag per observational unit. Specifically, while data on the predictor and moderator variables were obtained from non-finance directors (i.e., CEOs and export executives) in time one, data on the export performance variable was obtained from finance managers in time two. Despite these procedural measures taken to minimise common method bias threat, we also conducted ex-post statistical analysis to check if there was any evidence of method bias in our data. Following the marker variable procedure (Malhotra et al., 2006), we used the second smallest positive correlation between the study variables (i.e., .02) as a marker variable proxy and then calculated adjusted correlations among the variables. The adjustment did not 
change the significance level of any correlation coefficient, which suggests method bias does not pose a problem in this study.

\section{Analyses and Results}

Measurement Model Estimation

We examined construct validity using confirmatory factor analysis (CFA) implemented in EQS (6.3) statistical package. We used the maximum likelihood estimation method. The measurement model results indicate a good fitting model: $\left(\chi_{(221)}^{2}=587.59, p<.001 ; \mathrm{NFI}=.93, \mathrm{NNFI}=.95 ; \mathrm{CFI}=\right.$ .96 ; RMSEA $=0.08)$ with large and significant loadings $(t \geq 9.60)$ (see Table 3$)$. Moreover, for all constructs, the average variance extracted (AVE) estimates and composite reliability (CR) were above the recommended thresholds of 0.5 and 0.7 , respectively, which indicates convergent validity (Bagozzi and Yi, 2012). We followed Voorhees et al.'s (2016) recommendations to examine discriminant validity. First, we employed the AVE-shared variance comparison (Fornell and Larcker, 1981), and found that the AVE values for all constructs were higher than corresponding shared variances. Second, in line with Anderson and Gerbing (1988), we performed chi-square difference tests, and the results indicated significant chi-square differences between the constrained and unconstrained models $\left(\Delta \chi^{2}(1) \geq 3.84, p<0.05\right)$, indicating the presence of discriminant validity. Table 4 presents the descriptive statistics, inter-construct correlations and validity measures for the variables included in the analysis.

\section{[Insert Table 3 and Table 4]}

\section{Structural Model Estimation}

Having demonstrated the validity and reliability of all measures, we estimated a full structural equation model (SEM) to assess the hypothesised relationships using the maximum likelihood estimation method, implemented in EQS 6.3. The use of SEM provides benefits for a number of reasons. First, we argue that firm activities entail a web of interconnected behaviour and processes, 
and as such, relationships between various variables may look more complex than traditional multivariate analysis techniques (such as ANOVA multiple regression and logistic regression) can help to estimate (Tabachnick and Fidell, 2007). Second, SEM incorporates both observed and unobserved (i.e., latent) variables, while traditional methods are only based on observed measurements. Moreover, it provides researchers with the ability to estimate and account for measurement error in their data (Hair et al., 2017). Third, it is a well-tested and verified methodology for testing interval indirect effect relationships (Bagozzi and Yi, 2012). However, despite its benefits, we acknowledge that the use of SEM may also pose some challenges. One key challenge is the requirement for a relatively large sample size of subject-parameter ratio of 10:1 (Hair et al., 2017). Some simulation studies have suggested that a minimum of 200 sample size may be required to achieve satisfactory results (Yung and Bentler, 1994), which can be difficult to achieve in behavioural research.

In line with established procedures for testing moderated relationships, a multiplicative approach to SEM was adopted (Ping, 1995). The constructs that were used for multiplicative interactive analyses were mean centred to minimise any multicollinearity problem. We employed Ping's (1995) equations to estimate the loading and error variances of the interaction terms. We followed Mackinnon et al.'s (2002) recommendation to test the mediation model hierarchically (Lu et al., 2009; Boso et al., 2018b). First, we examined the full mediation model (baseline model) which does not have a path from independent variable (i.e., export learning orientation) to the dependent variable (i.e., export performance). The baseline model provides an acceptable model fit: $\left(\chi_{(273)}^{2}=\right.$ $807.05, p<.001 ; \mathrm{NFI}=.94, \mathrm{NNFI}=.95, \mathrm{CFI}=.95, \mathrm{RMSEA}=.09)$.

Second, we estimated a series of competing nested models against the baseline model, using sequential chi-square tests (see Table 5). In Model 1, the path for Hypothesis 1 was constrained to zero: that is, the path from export learning orientation to export performance was forced to take the value of zero. A non-significant increase in chi-square was observed, which suggests that the path is not an essential driver of export performance. Concerning Model 2, the path corresponding to 
Hypothesis 2 was constrained to zero: export learning orientation to marketing programme planning. A significant increase in chi-square was noted, thus providing support for the baseline model. In Model 3, the moderation paths were set to zero. A significant change in the chi-square difference suggests that the moderation paths are important.

Additionally, in Model 4 we compared the baseline model to a partial mediation model. In this case, one additional path was added to the baseline model: the direct path from export learning orientation (ELO) to export performance (EP). The result shows that the partial mediation model produces an acceptable model fit: $\left(\chi^{2}{ }_{(272)}=804.13, p<.001 ; \mathrm{NFI}=.95\right.$, NNFI $=.96, \mathrm{CFI}=.96$, RMSEA = .09). However, no significant chi-square difference was obtained: the p-value for the $\Delta \chi^{2}$ of 2.92 with one degree of freedom was not significant at $5 \%$ significance level. Although there is no statistically significant difference between the partial and the baseline full mediation models, we rely on the partial mediation for additional evaluation because it produces a smaller chi-square and a better fit to the data.

Consistent with the recommendations of Preacher and Hayes (2004; 2008), we conducted an additional mediation analysis with a bootstrap method in PROCESS to test the mediation effect relationship. The result confirms the mediating role of marketing programme planning in the relationship between export learning orientations and export performance $(\beta=.15,95 \%, \mathrm{LLCI}=.03$, $\mathrm{ULCI}=.27)$, demonstrating a similar pattern as those in the structural equation modelling.

We then tested three additional models to rule out alternative explanations. First, one could argue that there is no causal relationship between export learning orientation (a firm resource) and marketing programme planning (a firm capability), since capabilities are simply high order resources that contribute to export performance. To exclude this argument, we tested Model 5 (direct effect model) in which export learning orientation and marketing programme planning were directly linked to export performance. The chi-square difference test revealed that the partial mediation model was superior to the direct effect model $\left(\Delta \chi^{2}=16.79, \Delta d f=1, p<.05\right)$. Second, we ruled out the alternative explanation concerning the trivial role of marketing programme planning in enhancing export 
performance. To remove this argument, we tested a non-mediation model in which the path from marketing programme planning to export performance was constrained to zero. The result of the chisquare difference test indicates that marketing programme planning is a non-trivial variable in the model $\left(\Delta \chi^{2}=16.86, \Delta d f=2, p<.05\right)$. Finally, in Model 7, we excluded a potential reverse causality argument on the basis of a competing argument that marketing programme planning may cause firms to build their resource base to drive export performance. To counter this contention, we modelled marketing programme planning as an antecedent variable impacting on export learning orientation, and with export learning orientation directly linked to export performance. The overall fit indices show that this alternative model is significantly worse than our proposed conceptual model. Given these results, the partial mediation model best fit the data, and we rely on Model 4 in Table 6 to interpret our hypotheses. Table 6 presents the results of the standardised parameter estimates of the structural model. Overall, the model explains $37 \%$ of the total variance in export performance and $44 \%$ in marketing programme planning.

\section{[Insert Table 6]}

The study argues in $\mathrm{H} 1$ that export learning orientation relates positively to export performance. The study finds only marginal support for this hypothesis at $10 \%$ significant level $(\beta=.18 ; t=1.76 ; p$ $<0.10$ ). In $\mathrm{H} 2$, the study argues that marketing programme planning mediates the relationship between export learning orientation and export performance. The results show that export learning orientation is positively associated with marketing programme planning $(\beta=.63 ; t=6.70 ; p<.01)$, and the relationship between marketing programme planning and export performance is significant at $5 \%$ level $(\beta=.18 ; t=2.00 ; p<.05)$, providing support for Hypothesis 2 . Thus, we find empirical evidence to support our argument that marketing programme planning is the channel through which export learning orientation drives export performance.

The study argues in H3a that the effect of export learning orientation on export performance is weakened when perceived psychic distance is high, and in $\mathrm{H} 3 \mathrm{~b}$, the study contends that the effect of 
marketing programme planning on export performance is strengthened when the degree of perceived psychic distance is high. We find somewhat interesting and mixed results. Specifically, in support of $\mathrm{H} 3 \mathrm{a}$, at higher levels of psychic distance, the positive direct effect of export learning orientation on export performance is weakened, suggesting that the positive effect of export learning orientation on export performance is stronger when psychic distance takes on lower values $(\beta=-.14 ; t=-2.40 ; p<$ $.05)$. With respect to $\mathrm{H} 3 \mathrm{~b}$, findings show that when marketing programme planning takes on higher values and perceived psychic distance increases in magnitude, there is a significant positive effect of marketing programme planning on export performance $(\beta=.22 ; t=3.73 ; p<.01)$, which upholds our argument in $\mathrm{H} 3 \mathrm{~b}$.

\section{[Insert Table 6]}

\section{Additional Analyses}

Following Aiken and West (1991), we plotted the relationships between export learning orientation and marketing programme planning and export performance under differing levels of perceived psychic distance. Specifically, we assessed the effects of export learning orientation and marketing programme planning on export performance under high (one standard deviation above the mean values) versus low (one standard deviation below the mean values) of psychic distance. In Figure 2, we show that values below the mean value of psychic distance are associated with a stronger positive relationship between export learning orientation and export performance. Figure 3 demonstrates that when psychic distance takes on higher values above the mean, there is a corresponding stronger relationship between marketing programme planning and export performance.

\section{[Insert Figure 2 and Figure 3]}

\section{Controlling for endogeneity}

Following the growing tradition of addressing endogeneity with recognised methodological practices in management research (Zaefarian et al., 2017), we control for potential endogeneity in our conceptual model. Namely, we address any endogeneity presence pertaining to the complex nature 
and influence of psychic distance on the marketing programme planning and export performance relationship $^{1}$. In line with prior small business research (Booltink and Saka-Helmhout, 2018; McCann and Vroom, 2015; Scarlata et al., 2016), we employ the instrumental variables (IVs) approach, which involves a two-stage least squares (2SLS) regression, to mitigate endogeneity-related concerns (Bascle, 2008; Wooldridge, 2002). In the first stage, the endogenous variable is regressed on the chosen instruments, which are used as predictors, and the regression residual is saved in lieu of that variable. This procedure requires using instruments that are not correlated with the dependent variable, but are correlated with the independent (in our case - moderator), endogenous variable to be instrumented, thus ensuring the relevance and strength of the chosen instruments.

We treated international experience, the number of international export markets, organisation structure complexity, and export market intelligence dissemination as IVs, since each of these variables is expected to significantly affect psychic distance (the endogenous variable), but is not linked to export performance or marketing programme planning (Bascle, 2008). Based on Stock et al. (2002), the strength of the IVs can be measured by the $F$ statistic, which should reach 10 for strong instruments. In our case, the $F$ statistic from the first-stage regression of 2SLS used to instrument psychic distance showed a value of $F=9.689, p<0.01$. This indicates that the variables selected in our study served as relevant and strong instruments.

In the second stage, the residual saved from the first regression is used as an estimate of the psychic distance construct and is regressed together with the optimal model variables on firm performance (Wooldridge, 2002). Having implemented the second stage, the patterns of effects in the results obtained were identical to those presented in the analyses and results section of this study. Consequently, any presence of endogeneity in the psychic distance construct relationship with marketing programme planning and export performance is not distorting the key findings.

\footnotetext{
${ }^{1}$ We would like to thank one of the anonymous reviewers for this valuable suggestion on mitigating endogeneityrelated concerns in our research.
} 
Finally, one may argue that there may be differences in the relationships tested among high and low performers in our sample. To rule out this argument, we ran a multi-group model to test the relationships across high and low performing firms in our sample. We compared a constrained model (i.e., by imposing an equality constraint on the hypothesised structural paths) to an unconstrained model (i.e., by allowing all parameter estimates to vary between the two groups), and found that while the unconstrained model yielded $\chi_{(544)}^{2}=1296.008, p=.001$, the constrained model yields $\chi_{(546)}^{2}=1297.676, p=.001$. The insignificant chi-square difference between the two models $\left(\Delta \chi^{2}=\right.$ 1.688, $\Delta d f=2, p>.05$ ) indicates that there is no significant difference between the two groups of firms.

\section{Discussion and implications}

The purpose of this study is to examine marketing programme planning and perceived psychic distance conditions under which export learning drives export performance. In empirically examining this conceptual framework on data obtained from exporting SMEs in Nigeria, this study adds to the small business literature by showing the mechanisms and conditions that link export learning to export performance (e.g., Real et al., 2014; Wang, 2008; Baker and Sinkula, 1999; Calantone et al., 2002; Sinkula et al., 1997). Contrary to the hypothesised associations, our findings demonstrate that export learning orientation is not significantly related to export performance. This suggests that being oriented towards learning alone is not sufficient for a firm to achieve enhanced performance (Suliyanto and Rahab, 2012). In other words, merely acquiring and accumulating export knowledge is not enough to boost export performance, because knowledge is meant to be used and applied to certain organisational practices and policies to aid managerial decision-making. Rather, acquired and accumulated export market knowledge that accrues to firms as a result of being oriented to export learning, should be deployed to enrich internal export-market related marketing programme activities to increase export performance (Alpkan et al., 2007; Oliva and Watson, 2011). In line with the traditional resource-based theory, our results show that marketing planning programme fully mediates the relationship between export learning 
orientation and export performance. Thus, in taking a resource-based theoretical argument, findings imply that export learning orientation knowledge-based firm resources should be used to develop exporting related marketing programme plans to drive performance in export markets. This can be done by using the knowledge generated from export markets to feed into the design, formulation, and implementation of marketing programmes. For exporting SMEs such as those studied in this study, a well-defined and welldesigned marketing programmes driven by accumulated export knowledge can help newly internationalising firms turn their export learning proclivity into an enhanced export performance (Alpkan et al., 2007; Conant and White, 1999).

Our findings add to the growing number of studies investigating the importance of psychic distance in exporting and internationalisation in general (Johnston et al., 2012; Morgan et al., 2012). We have sought to broaden the understanding of the psychic distance paradox (Evans and Mavondo, 2002; O'Grady and Lane, 1996; Zaheer and Hernandez, 2011) and its implications for small and medium-sized exporting firms and their performance. We find that psychic distance negatively moderates the link between export learning orientation and export performance. However, conversely to our expectations and in favour of the existing paradoxical evidence, its conditioning effect becomes positive on the relationship between marketing programme planning and export performance. In this light, our results strongly emphasise that high export learning orientation alone is not enough to improve export performance. It might even become damaging for a firm exporting to psychically distant countries, potentially owing to efforts put primarily to acquire knowledge but not to adapt internal planning and operations responsible for smooth internationalisation.

At the same time, our findings suggest that when exporting to markets with high psychic distance, the role of planning and having a clear marketing programme in improving export performance increases. Potentially, companies exporting to markets with higher psychic distance put more effort into their planning activities related to marketing programme design and implementation, anticipating future challenges and the potential impact of working in such countries. Therefore, it is possible to assume that under high psychic distance conditions and expected issues related to it, firms 
contribute a lot more time and resources to design especially sturdy and effective marketing programmes. Based on the above, we add to the psychic distance and internationalisation literature within exporting context (Evans et al., 2000; Sousa and Bradley, 2006) by expanding our understanding of how such complex markets with high psychic distance can be not only barriers to export performance but also facilitators for the successful planning and implementation of marketing programmes boosting export performance.

The value of this article also extends to practitioners. Managers of small to medium-sized internationalising firms, particularly those who are involved in exporting activities, can benefit from the identification of factors found to influence export performance. Exporting companies utilise their acquired knowledge to increase the likelihood of improving their performance; however, our findings suggest that learning alone, as proactive as it may be, is not a sufficient component for the international success of a firm. Moreover, the effect of export learning orientation on export performance becomes negative under the conditions of high psychic distance of foreign markets. Nonetheless, export learning orientation is found to make a significant contribution to export performance through marketing programme planning. Thus, the potential influence of marketing programme planning identified in this research can serve in the form of developing a tactical planning tool, guiding a firm's decisions regarding export strategy and its implementation, as well as internationalisation overall. By being made aware of the crucial importance of a clear, defined, and realistic marketing programme, managers will be better prepared to recognise and adapt to internal and external influences of foreign markets.

Specifically, having a clear and robust marketing programme becomes an essential prerequisite for success when exporting to psychically distant and thus difficult, less predictable markets. We suggest that firms with intentions to export or actively exporting to such markets, should utilise the benefits of planning and implementing a distinct marketing programme, which would facilitate the process of executing ongoing marketing decisions and smooth business operations, and furthermore, dealing with foreign market uncertainties. Importantly, the planning and development of such 
programmes should take place in tandem with export learning activities, with the latter informing and guiding the former.

\section{Limitations and future research}

As with any study, our results should be interpreted considering some limitations. First, we must point out that certain bias may be present, since all the measures in this study are of a perceptual nature. At the same time, since the study relies on cross-sectional data, the causal attribution of relationships is relatively weak. Hence, future research could add greater rigour to our results by adopting a longitudinal approach in the study of the relationships.

Second, we conducted the study within the context of one country. However, there are good theoretical reasons to believe that firms in other emerging markets may experience similar dynamics. Nonetheless, even though Nigeria undoubtedly represents an emerging market and we expect that our findings will hold for other markets of a similar kind, the focus on a single country context may limit the generalisability of the results to some degree. Thus, a useful extension would be to conduct this study in South East Asian countries (e.g., China and India), Eastern European countries (e.g., Poland and the Baltics) and South American countries (e.g., Brazil, Chile, and Peru).

Finally, although we have given attention to operationalising the study constructs with a sufficient degree of theoretical rigour and measurement validation, further research should explore the relevance of other constructs in the assessment of these relationships. For example, the use of new constructs to test for additional moderating effects of both internal and external influences, such as internationalisation speeds and breadth, managerial commitment and experience, market turbulence and munificence, could help expand the existing understanding of the importance of marketing programme planning and the role of psychic distance in shaping its relationship with export performance. Thus, there is considerable scope for future research to contribute with new related variables and with attempts to strengthen, clarify or advance our findings. 


\section{Conclusions}

In conclusion, our findings suggest that exporting SMEs need to develop strong marketing programme planning practices to ensure that the knowledge acquired in export learning is effectively translated into export performance. Additionally, we find that psychic distance negatively moderates the relationship between export learning orientation and export performance, but positively moderates the link between marketing programme planning and export performance. In other words, when psychic distance between a firm's home and host country is high, the effect of export learning on performance is weakened but strengthens the effect of marketing programme planning on export performance. 


\section{References}

Acquaah M. (2012) Social networking relationships, firm-specific managerial experience and firm performance in a transition economy: A comparative analysis of family owned and nonfamily firms. Strategic Management Journal 33: 1215-1228.

Aiken LS and West SG. (1991) Multiple regression: Testing and interpreting interactions, Newbury Park, CA: Sage.

Allen IE and Seaman CA. (2007) Likert scales and data analyses. Quality progress 40: 64-65.

Alpkan L, Yilmaz C and Kaya N. (2007) Market orientation and planning flexibility in SMEs performance implications and an empirical investigation. International Small Business Journal 25: 152-172.

Anderson JC and Gerbing DW. (1988) Structural equation modeling in practice: A review and recommended two-step approach. Psychological bulletin 103: 411-423.

Atuahene-Gima K and Murray JY. (2007) Exploratory and exploitative learning in new product development: A social capital perspective on new technology ventures in China. Journal of International Marketing 15: 1-29.

Bagozzi RP and Yi Y. (2012) Specification, evaluation, and interpretation of structural equation models. Journal of the Academy of Marketing Science 40: 8-34.

Baker WE and Sinkula JM. (1999) The synergistic effect of market orientation and learning orientation on organizational performance. Journal of the Academy of Marketing Science 27: 411-427.

Bascle G. (2008) Controlling for endogeneity with instrumental variables in strategic management research. Strategic Organization 6: 285-327.

Beneke J, Beneke J, Blampied S, et al. (2016) The impact of market orientation and learning orientation on organisational performance: A study of small to medium-sized enterprises in Cape Town, South Africa. Journal of Research in Marketing and Entrepreneurship 18: 90108.

Booltink LW and Saka-Helmhout A. (2018) The effects of r\&d intensity and internationalization on the performance of non-high-tech SMEs. International Small Business Journal 36: 81-103.

Boso N, Adeleye I, Ibeh K, et al. (2018a) The internationalization of African firms: Opportunities, challenges, and risks. Thunderbird International Business Review.

Boso N, Adeola O, Danso A, et al. (2017) The effect of export marketing capabilities on export performance: Moderating role of dysfunctional competition. Industrial Marketing Management.

Boso N, Annan J, Adeleye I, et al. (2018b) Examining the paths from export strategic orientations to export performance: The mediating role of export resource transformation capability. Thunderbird International Business Review 60: 207-230.

Boso N, Oghazi P, Cadogan JW, et al. (2016) Entrepreneurial and market-oriented activities, financial capital, environment turbulence, and export performance in an emerging economy. Journal of Small Business Strategy 26: 1-24.

Brock JK-U, Johnson JE and Zhou JY. (2011) Does distance matter for internationally-oriented small firms? Industrial Marketing Management 40: 384-394.

Bunderson JS and Sutcliffe KM. (2003) Management team learning orientation and business unit performance. Journal of Applied Psychology 88: 552.

Cadogan JW, Boso N, Story VM, et al. (2016) Export strategic orientation-performance relationship: Examination of its enabling and disenabling boundary conditions. Journal of Business Research 69: 5046-5052.

Calantone RJ, Cavusgil ST and Zhao Y. (2002) Learning orientation, firm innovation capability, and firm performance. Industrial Marketing Management 31: 515-524.

Carson SJ, Madhok A and Wu T. (2006) Uncertainty, opportunism, and governance: The effects of volatility and ambiguity on formal and relational contracting. Academy of Management Journal 49: 1058-1077. 
Cavusgil ST and Cavusgil E. (2012) Reflections on international marketing: Destructive regeneration and multinational firms. Journal of the Academy of Marketing Science 40: 202-217.

Chabowski B, Kekec P, Morgan NA, et al. (2018) An assessment of the exporting literature: Using theory and data to identify future research directions. Journal of International Marketing 26: 118-143.

Charoensukmongkol P. (2016) Cultural intelligence and export performance of small and medium enterprises in Thailand: Mediating roles of organizational capabilities. International Small Business Journal 34: 105-122.

Child J, Ng SH and Wong C. (2002) Psychic distance and internationalization: Evidence from Hong Kong firms. International Studies of Management \& Organization 32: 36-56.

Chung HF, Yang Z and Huang P-H. (2015) How does organizational learning matter in strategic business performance? The contingency role of guanxi networking. Journal of Business Research 68: 1216-1224.

CIA. (2018) The world factbook. Available at: https://www.cia.gov/library/publications/the-worldfactbook/geos/ni.html.

Conant JS and White JC. (1999) Marketing programme planning, process benefits, and store performance: An initial study among small retail firms. Journal of Retailing 75: 525-541.

De Winter JC and Dodou D. (2010) Five-point Likert items: T test versus Mann-Whitney-Wilcoxon. Practical Assessment, Research \& Evaluation 15: 2.

Devellis RF. (2011) Scale development: Theory and applications: Sage Publications, Incorporated.

Dow D and Karunaratna A. (2006) Developing a multidimensional instrument to measure psychic distance stimuli. Journal of International Business Studies 37: 578-602.

Ellis PD, Davies H and Wong AH-K. (2011) Export intensity and marketing in transition economies: Evidence from China. Industrial Marketing Management 40: 593-602.

Evans J and Mavondo FT. (2002) Psychic distance and organizational performance: An empirical examination of international retailing operations. Journal of International Business Studies 33: 515-532.

Evans J, Treadgold A and Mavondo F. (2000) Explaining export development through psychic distance. International Marketing Review 17: 164-169.

Fornell C and Larcker DF. (1981) Evaluating structural equation models with unobservable variables and measurement error. Journal of Marketing Research 18: 39-50.

Gaur AS and Lu JW. (2007) Ownership strategies and survival of foreign subsidiaries: Impacts of institutional distance and experience. Journal of Management 33: 84-110.

Gnizy I, Cadogan JW, Oliveira JS, et al. (2017) The empirical link between export dispersion and export performance: A contingency-based approach. International Business Review 26: 239249.

Gnizy I, E. Baker W and Grinstein A. (2014) Proactive learning culture: A dynamic capability and key success factor for SMEs entering foreign markets. International Marketing Review 31: 477-505.

Hair JF, Hult GTM, Ringle CM, et al. (2017) Mirror, mirror on the wall: A comparative evaluation of composite-based structural equation modeling methods. Journal of the Academy of Marketing Science 45: 616-632.

Hakala H. (2011) Strategic orientations in management literature: Three approaches to understanding the interaction between market, technology, entrepreneurial and learning orientations. International Journal of Management Reviews 13: 199-217.

Ho MH-W and Wang F. (2015) Unpacking knowledge transfer and learning paradoxes in international strategic alliances: Contextual differences matter. International Business Review 24: 287-297.

Hult GTM, Ketchen DJ, Griffith DA, et al. (2008) An assessment of the measurement of performance in international business research. Journal of International Business Studies 39: 1064-1080.

Hurley RF and Hult GTM. (1998) Innovation, market orientation, and organizational learning: An integration and empirical examination. Journal of Marketing 62: 42-54. 
Håkanson L and Ambos B. (2010) The antecedents of psychic distance. Journal of International Management 16: 195-210.

Ibeh K, Wilson J and Chizema A. (2012) The internationalization of African firms 1995-2011: Review and implications. Thunderbird International Business Review 54: 411-427.

Jay J. (2013) Navigating paradox as a mechanism of change and innovation in hybrid organizations. Academy of Management Journal 56: 137-159.

Johnston WJ, Khalil S, Jain M, et al. (2012) Determinants of joint action in international channels of distribution: The moderating role of psychic distance. Journal of International Marketing 20: 34-49.

Katsikeas CS, Morgan NA, Leonidou LC, et al. (2016) Assessing performance outcomes in marketing. Journal of Marketing 80: 1-20.

Khavul S, Pérez-Nordtvedt L and Wood E. (2010) Organizational entrainment and international new ventures from emerging markets. Journal of Business Venturing 25: 104-119.

Kim N and Atuahene-Gima K. (2010) Using exploratory and exploitative market learning for new product development. Journal of Product Innovation Management 27: 519-536.

Kropp F, Lindsay NJ and Shoham A. (2006) Entrepreneurial, market, and learning orientations and international entrepreneurial business venture performance in south African firms. International Marketing Review 23: 504-523.

Kuivalainen O, Sundqvist S and Servais P. (2007) Firms' degree of born-globalness, international entrepreneurial orientation and export performance. Journal of World Business 42: 253-267.

Lado AA, Boyd NG, Wright P, et al. (2006) Paradox and theorizing within the resource-based view. Academy of Management Review 31: 115-131.

Lee $\mathrm{H}$ and Choi B. (2003) Knowledge management enablers, processes, and organizational performance: An integrative view and empirical examination. Journal of Management Information Systems 20: 179-228.

Leonard D. (1992) Core capabilities and core rigidities: A paradox in managing new product development. Strategic Management Journal 13: 111-125.

Leonidou LC, Katsikeas CS and Coudounaris DN. (2010) Five decades of business research into exporting: A bibliographic analysis. Journal of International Management 16: 78-91.

Lu Y, Zhou L, Bruton G, et al. (2009) Capabilities as a mediator linking resources and the international performance of entrepreneurial firms in an emerging economy. Journal of International Business Studies 41: 419-436.

Lysonski S and Pecotich A. (1992) Strategic marketing planning, environmental uncertainty and performance. International Journal of Research in Marketing 9: 247-255.

Mackinnon DP, Lockwood CM, Hoffman JM, et al. (2002) A comparison of methods to test mediation and other intervening variable effects. Psychological methods 7: 83-104.

Malhotra NK, Kim SS and Patil A. (2006) Common method variance in is research: A comparison of alternative approaches and a reanalysis of past research. Management Science 52: 18651883.

Matanda MJ, Ndubisi NO and Jie F. (2016) Effects of relational capabilities and power asymmetry on innovativeness and flexibility of Sub-Sahara Africa small exporting firms. Journal of Small Business Management 54: 118-138.

Mattsson L-G and Tidström A. (2015) Applying the principles of yin-yang to market dynamics: On the duality of cooperation and competition. Marketing Theory 15: 347-364.

Mccann BT and Vroom G. (2015) Opportunity evaluation and changing beliefs during the nascent entrepreneurial process. International Small Business Journal 33: 612-637.

Morgan NA, Feng H and Whitler KA. (2018) Marketing capabilities in international marketing. Journal of International Marketing 26: 61-95.

Morgan NA, Kaleka A and Katsikeas CS. (2004) Antecedents of export venture performance: A theoretical model and empirical assessment. Journal of Marketing 68: 90-108. 
Morgan NA, Katsikeas CS and Vorhies DW. (2012) Export marketing strategy implementation, export marketing capabilities, and export venture performance. Journal of the Academy of Marketing Science 40: 271-289.

Murray JY, Gao GY and Kotabe M. (2011) Market orientation and performance of export ventures: The process through marketing capabilities and competitive advantages. Journal of the Academy of Marketing Science 39: 252-269.

Naldi L and Davidsson P. (2014) Entrepreneurial growth: The role of international knowledge acquisition as moderated by firm age. Journal of Business Venturing 29: 687-703.

Noh M, Kim H and Jang H. (2016) Learning performance and business performance of knowledge management organizations: The moderating effect of technological capability. Information Development 32: 637-654.

O'grady S and Lane HW. (1996) The psychic distance paradox. Journal of International Business Studies 27: 309-333.

Oliva R and Watson N. (2011) Cross-functional alignment in supply chain planning: A case study of sales and operations planning. Journal of Operations Management 29: 434-448.

Ortega-Argilés R, Vivarelli M and Voigt P. (2009) R\&d in SMEs: A paradox? Small Business Economics 33: 3-11.

Pearsall MJ and Venkataramani V. (2015) Overcoming asymmetric goals in teams: The interactive roles of team learning orientation and team identification. Journal of Applied Psychology 100: 735.

Ping RA. (1995) A parsimonious estimating technique for interaction and quadratic latent variables. Journal of Marketing Research 32: 336-347.

Podsakoff PM, Mackenzie SB and Podsakoff NP. (2012) Sources of method bias in social science research and recommendations on how to control it. Annual review of psychology 63: 539569.

Preacher KJ and Hayes AF. (2004) SPSS and SAS procedures for estimating indirect effects in simple mediation models. Behavior Research Methods 36: 717-731.

Preacher KJ and Hayes AF. (2008) Asymptotic and resampling strategies for assessing and comparing indirect effects in multiple mediator models. Behavior Research Methods 40: 879-891.

Putnam LL, Fairhurst GT and Banghart S. (2016) Contradictions, dialectics, and paradoxes in organizations: A constitutive approach. The Academy of Management Annals 10: 65-171.

Rauch A, Wiklund J, Lumpkin GT, et al. (2009) Entrepreneurial orientation and business performance: An assessment of past research and suggestions for the future. Entrepreneurship Theory and Practice 33: 761-787.

Real JC, Roldán JL and Leal A. (2014) From entrepreneurial orientation and learning orientation to business performance: Analysing the mediating role of organizational learning and the moderating effects of organizational size. British Journal of Management 25: 186-208.

Scarlata M, Zacharakis A and Walske J. (2016) The effect of founder experience on the performance of philanthropic venture capital firms. International Small Business Journal 34: 618-636.

Schad J, Lewis MW, Raisch S, et al. (2016) Paradox research in management science: Looking back to move forward. The Academy of Management Annals 10: 5-64.

Schilling MA. (2002) Technology success and failure in winner-take-all markets: The impact of learning orientation, timing, and network externalities. Academy of Management Journal 45: 387-398.

Sinkula JM, Baker WE and Noordewier T. (1997) A framework for market-based organizational learning: Linking values, knowledge, and behavior. Journal of the Academy of Marketing Science 25: 305-318.

Skarmeas D, Lisboa A and Saridakis C. (2016) Export performance as a function of market learning capabilities and intrapreneurship: Sem and fsQCA findings. Journal of Business Research 69: 5342-5347.

Slater SF and Narver JC. (1995) Market orientation and the learning organization. The Journal of Marketing: 63-74. 
Slotegraaf RJ and Dickson PR. (2004) The paradox of a marketing planning capability. Journal of the Academy of Marketing Science 32: 371-385.

Smith WK and Lewis MW. (2011) Toward a theory of paradox: A dynamic equilibrium model of organizing. Academy of Management Review 36: 381-403.

Smith WK and Tracey P. (2016) Institutional complexity and paradox theory: Complementarities of competing demands. Strategic Organization 14: 455-466.

Sousa CM and Bradley F. (2006) Cultural distance and psychic distance: Two peas in a pod? Journal of International Marketing 14: 49-70.

Sousa CM and Lages LF. (2011) The pd scale: A measure of psychic distance and its impact on international marketing strategy. International Marketing Review 28: 201-222.

Stock JH, Wright JH and Yogo M. (2002) A survey of weak instruments and weak identification in generalized method of moments. Journal of Business \& Economic Statistics 20: 518-529.

Stöttinger B and Schlegelmilch BB. (1998) Explaining export development through psychic distance: Enlightening or elusive? International Marketing Review 15: 357-372.

Suliyanto S and Rahab R. (2012) The role of market orientation and learning orientation in improving innovativeness and performance of small and medium enterprises. Asian Social Science 8: 134.

Tabachnick BG and Fidell LS. (2007) Using multivariate statistics: Allyn \& Bacon/Pearson Education.

Tajeddini K. (2016) Analyzing the influence of learning orientation and innovativeness on performance of public organizations: The case of Iran. Journal of Management Development 35: 134-153.

Tasavori M, Zaefarian R and Eng T-Y. (2018) Internal social capital and international firm performance in emerging market family firms: The mediating role of participative governance. International Small Business Journal: 1-24.

Taylor M and Jack R. (2013) Understanding the pace, scale and pattern of firm internationalization: An extension of the 'born global' concept. International Small Business Journal 31: 701-721.

Theodosiou M and Katsikea E. (2013) The export information system: An empirical investigation of its antecedents and performance outcomes. Journal of International Marketing 21: 72-94.

Tobacyk JJ. (2004) A revised paranormal belief scale. International Journal of Transpersonal Studies 23: 11 .

Tse CH, Yu L and Zhu J. (2017) A multimediation model of learning by exporting: Analysis of export-induced productivity gains. Journal of Management 43: 2118-2146.

Vandenbosch B and Higgins C. (1996) Information acquisition and mental models: An investigation into the relationship between behaviour and learning. Information Systems Research 7: 198214.

Vij S and Farooq R. (2015) The relationship between learning orientation and business performance: Do smaller firms gain more from learning orientation? IUP Journal of Knowledge Management 13: 7.

Villar C, Alegre J and Pla-Barber J. (2014) Exploring the role of knowledge management practices on exports: A dynamic capabilities view. International Business Review 23: 38-44.

Volery T, Mueller S and Von Siemens B. (2015) Entrepreneur ambidexterity: A study of entrepreneur behaviours and competencies in growth-oriented small and medium-sized enterprises. International Small Business Journal 33: 109-129.

Voorhees CM, Brady MK, Calantone R, et al. (2016) Discriminant validity testing in marketing: An analysis, causes for concern, and proposed remedies. Journal of the Academy of Marketing Science 44: 119-134.

Wang CL. (2008) Entrepreneurial orientation, learning orientation, and firm performance. Entrepreneurship Theory and Practice 32: 635-657.

Wooldridge JM. (2002) Econometric analysis of cross section and panel data, Cambridge, MA: MIT Press. 
Yung YF and Bentler PM. (1994) Bootstrap-corrected ADF test statistics in covariance structure analysis. British Journal of Mathematical and Statistical Psychology 47: 63-84.

Zaefarian G, Kadile V, Henneberg SC, et al. (2017) Endogeneity bias in marketing research: Problem, causes and remedies. Industrial Marketing Management 65: 39-46.

Zaheer A and Hernandez E. (2011) The geographic scope of the MNC and its alliance portfolio: Resolving the paradox of distance. Global Strategy Journal 1: 109-126.

Zhang X, Ma X and Wang Y. (2012) Entrepreneurial orientation, social capital, and the internationalization of SMEs: Evidence from China. Thunderbird International Business Review 54: 195-210.

Zou S, Fang E and Zhao S. (2003) The effect of export marketing capabilities on export performance: An investigation of Chinese exporters. Journal of International Marketing 11: 32-55. 
Figure 1: Theoretical Framework

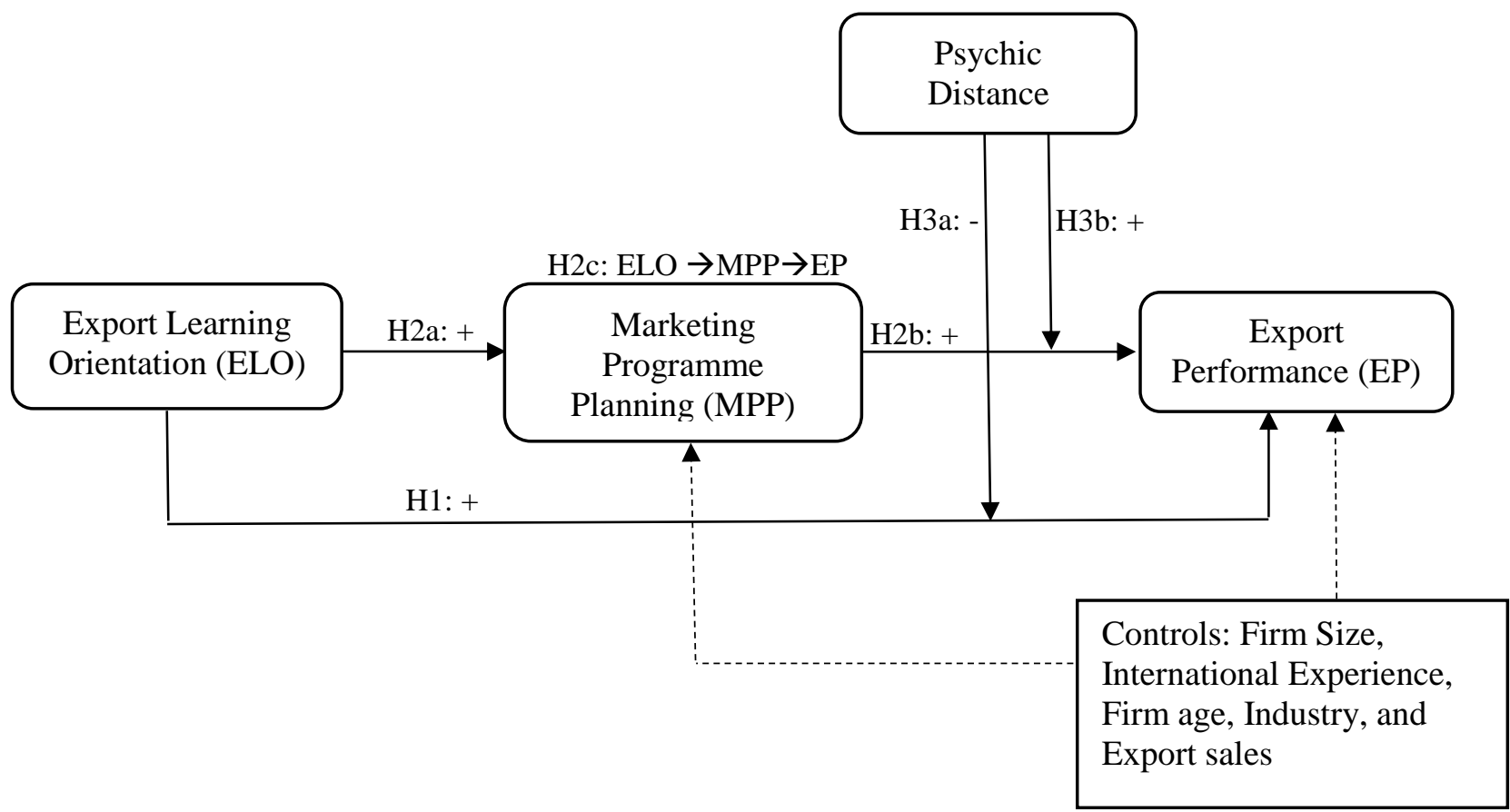


Figure 2: Surface Plot of the Moderating Effect of Psychic Distance on Export Learning Orientation-Export Performance Relationship

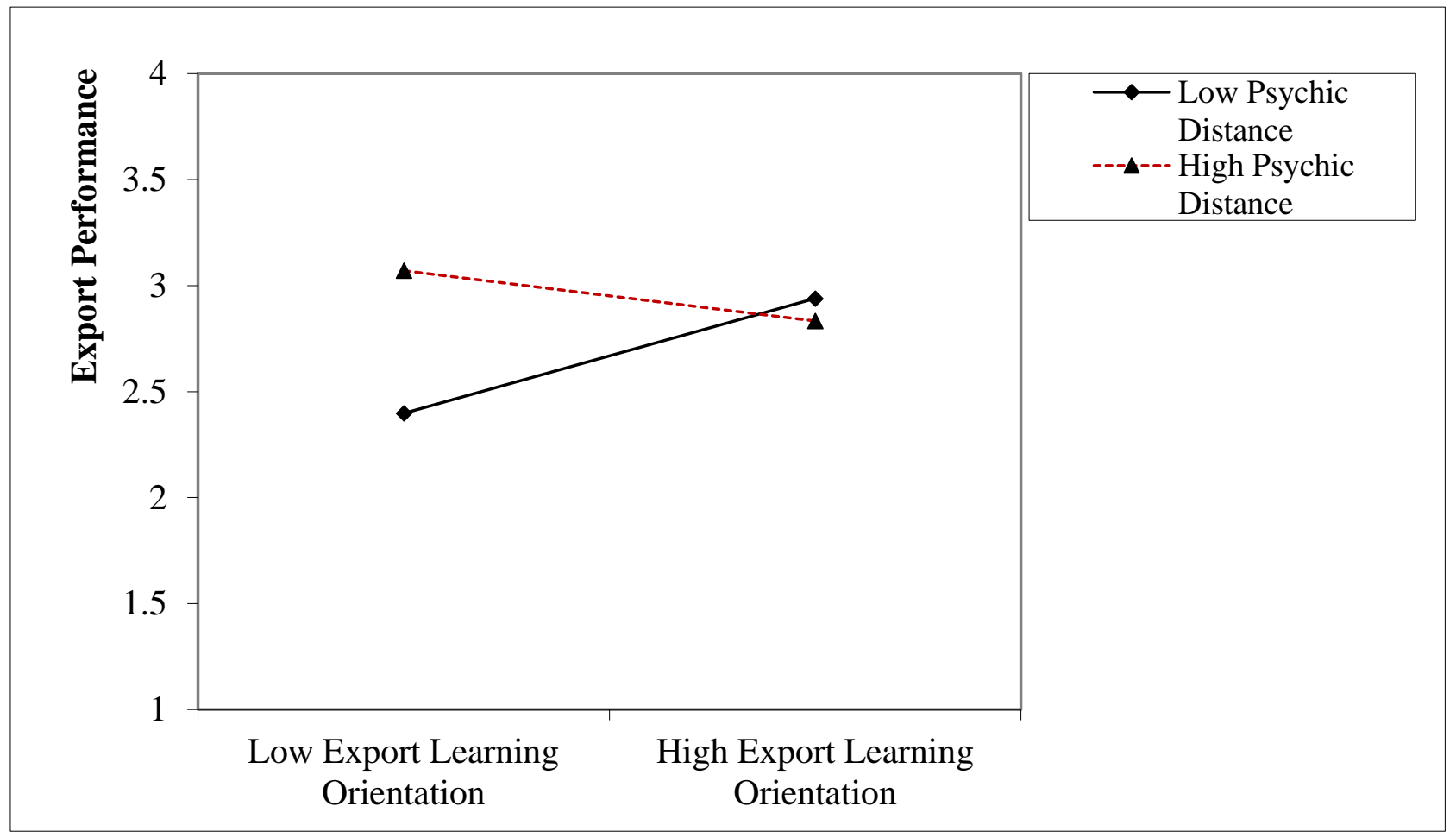

Figure 3: Surface Plot of the Moderating Effect of Psychic Distance on Marketing Programme Planning-Export Performance Relationship

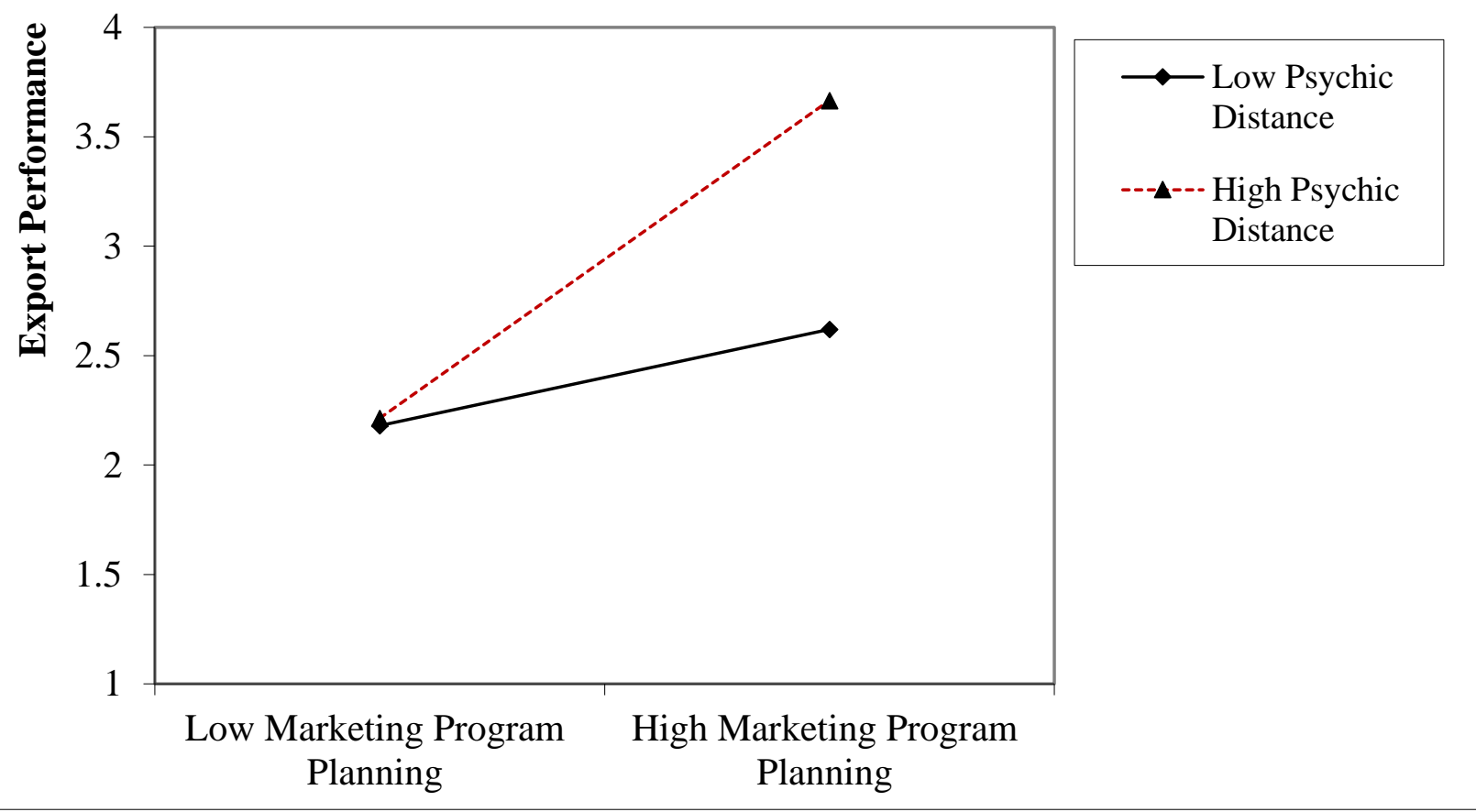


Table 1: Empirical contributions on learning orientation and performance

\begin{tabular}{|c|c|c|c|c|}
\hline Authors & Method and Sample & Operationalisation of Learning Orientation & Relevant Findings & Relevant Avenues for Further Studies \\
\hline $\begin{array}{l}\text { Noh et al. } \\
(2016)\end{array}$ & $\begin{array}{l}\text { Survey - } 108 \text { (chief } \\
\text { knowledge and information } \\
\text { officers) }\end{array}$ & $\begin{array}{l}\text { The degree to which learning is encouraged in } \\
\text { an organisation ( } 3 \text { items from Hurley and Hult } \\
\text { (1998), Lee and Choi (2003)); and Learning } \\
\text { performance (4 items from Vandenbosch and } \\
\text { Higgins (1996)) }\end{array}$ & $\begin{array}{l}\text { Learning has a positive effect on } \\
\text { knowledge creation and sharing, } \\
\text { which in turn improves business } \\
\text { performance. }\end{array}$ & $\begin{array}{l}\text { To advance the body of knowledge on learning by } \\
\text { testing it in different cultures }\end{array}$ \\
\hline $\begin{array}{l}\text { Beneke et al. } \\
(2016)\end{array}$ & $\begin{array}{l}\text { Survey - } 162 \text { (senior } \\
\text { managers) }\end{array}$ & $\begin{array}{l}\text { Second-order construct with } 4 \text { dimensions: } \\
\text { commitment to learning, shared vision, open- } \\
\text { mindedness and intra-organisational } \\
\text { knowledge sharing (Calantone et al., 2002) }\end{array}$ & $\begin{array}{l}\text { Learning orientation has no } \\
\text { significant effect on organisational } \\
\text { performance }\end{array}$ & $\begin{array}{l}\text { To confirm the effects of learning orientation on } \\
\text { organisational performance by applying } \\
\text { longitudinal survey design }\end{array}$ \\
\hline $\begin{array}{l}\text { Tajeddini } \\
(2016)\end{array}$ & $\begin{array}{l}\text { Survey - } 127 \text { (senior } \\
\text { managers) }\end{array}$ & $\begin{array}{l}4 \text { items from Hult et al. (2000) and Sinkula et } \\
\text { al. (1997) }\end{array}$ & $\begin{array}{l}\text { Learning orientation has a positive } \\
\text { effect on organisational performance }\end{array}$ & $\begin{array}{l}\text { To confirm the effects of learning orientation on } \\
\text { organisational performance by applying } \\
\text { longitudinal survey design }\end{array}$ \\
\hline $\begin{array}{l}\text { Vij and Farooq } \\
(2015)\end{array}$ & $\begin{array}{l}\text { Survey - } 278 \text { (senior level } \\
\text { managers) }\end{array}$ & $\begin{array}{l}10 \text { items from Slater and Narver (1995), } \\
\text { Sinkula et al. (1997), and Calantone et al. } \\
(2002)\end{array}$ & $\begin{array}{l}\text { Learning orientation has a positive } \\
\text { effect on business performance }\end{array}$ & $\begin{array}{l}\text { Consideration of moderating factors of the learning } \\
\text { orientation - business performance relationship is } \\
\text { proposed }\end{array}$ \\
\hline $\begin{array}{l}\text { Pearsall and } \\
\text { Venkataramani } \\
(2015)\end{array}$ & $\begin{array}{l}\text { Experiment - } 280 \text { (student } \\
\text { teams) }\end{array}$ & 5 items from Bunderson and Sutcliffe (2003) & $\begin{array}{l}\text { Learning orientation has a positive } \\
\text { effect on team performance }\end{array}$ & $\begin{array}{l}\text { Consideration of moderating factors of the learning } \\
\text { orientation - team performance relationship is } \\
\text { proposed }\end{array}$ \\
\hline $\begin{array}{l}\text { Chung et al. } \\
(2015)\end{array}$ & Survey - 120 (senior staff) & $\begin{array}{l}\text { Explorative and exploitative learning ( } 10 \\
\text { items from Atuahene-Gima and Murray } \\
\text { (2007) and Kim and Atuahene-Gima (2010) }\end{array}$ & $\begin{array}{l}\text { Explorative and exploitative learning } \\
\text { have no significant effect on strategic } \\
\text { performance (but this effect becomes } \\
\text { significant when moderated by } \\
\text { guanxi networking) }\end{array}$ & $\begin{array}{l}\text { To advance the body of knowledge on learning by } \\
\text { testing it in different cultures } \\
\text { Consideration of other moderating factors of the } \\
\text { learning - performance relationship is proposed }\end{array}$ \\
\hline $\begin{array}{l}\text { Real et al. } \\
(2014)\end{array}$ & Survey -140 (CEOs) & $\begin{array}{l}\text { Second-order construct with } 3 \text { dimensions: } \\
\text { commitment to learning, shared vision, and } \\
\text { open-mindedness }\end{array}$ & $\begin{array}{l}\text { Organisational learning mediates the } \\
\text { relationship between learning } \\
\text { orientation and business performance }\end{array}$ & \\
\hline
\end{tabular}




\section{Table 1 continued}

\begin{tabular}{|c|c|c|c|c|}
\hline Authors & Method and Sample & $\begin{array}{l}\text { Operationalisation of Learning } \\
\text { Orientation }\end{array}$ & Relevant Findings & Relevant Avenues for Further Studies \\
\hline $\begin{array}{l}\text { Suliyanto and } \\
\text { Rahab (2012) }\end{array}$ & Survey - 200 (entrepreneurs) & $\begin{array}{l}\text { Systematical commitment to problem- } \\
\text { solving (items from Calantone et al. } \\
\text { (2002) }\end{array}$ & $\begin{array}{l}\text { Learning orientation has a positive effect on } \\
\text { innovation performance }\end{array}$ & $\begin{array}{l}\text { Consideration of moderating factors of the } \\
\text { learning orientation - innovation performance } \\
\text { relationship is proposed }\end{array}$ \\
\hline Wang (2008) & Survey - 213 (senior executives) & $\begin{array}{l}\text { Second-order construct with } 3 \\
\text { dimensions: commitment to learning, } \\
\text { shared vision, and open-mindedness }\end{array}$ & $\begin{array}{l}\text { Learning orientation mediates the relationship } \\
\text { between entrepreneurial orientation and firm } \\
\text { performance. }\end{array}$ & $\begin{array}{l}\text { The learning orientation - performance } \\
\text { relationship should be examined among new } \\
\text { ventures }\end{array}$ \\
\hline $\begin{array}{l}\text { Kropp et al. } \\
(2006)\end{array}$ & $\begin{array}{l}\text { Survey - } 373 \text { INVs }(539 \\
\text { entrepreneurs and senior } \\
\text { managers) }\end{array}$ & $\begin{array}{l}4 \text { items from Hult et al.'s (1999) } \\
\text { multidimensional orientations scale }\end{array}$ & $\begin{array}{l}\text { Learning orientation has a positive effect on } \\
\text { performance }\end{array}$ & $\begin{array}{l}\text { There is a need to allow a time lag between } \\
\text { learning orientation and performance }\end{array}$ \\
\hline $\begin{array}{l}\text { Calantone et al. } \\
(2002)\end{array}$ & Survey - 187 (senior executives) & $\begin{array}{l}\text { Second-order construct with } 4 \\
\text { dimensions: commitment to learning, } \\
\text { shared vision, open-mindedness and } \\
\text { intra-organisational knowledge sharing. }\end{array}$ & $\begin{array}{l}\text { Learning orientation has a positive effect on } \\
\text { performance. }\end{array}$ & $\begin{array}{l}\text { To advance the body of knowledge on } \\
\text { learning by testing its effect in more exotic } \\
\text { cultures }\end{array}$ \\
\hline $\begin{array}{l}\text { Baker and } \\
\text { Sinkula (1999) }\end{array}$ & Survey - 411 (senior executives) & $\begin{array}{l}\text { Second-order construct with } 3 \\
\text { dimensions: commitment to learning, } \\
\text { shared vision, and open-mindedness } \\
\text { (Sinkula et al., 1997) }\end{array}$ & $\begin{array}{l}\text { Learning orientation has a positive on } \\
\text { performance (including market share change, } \\
\text { new product success. }\end{array}$ & $\begin{array}{l}\text { To examine the effects also in smaller, } \\
\text { struggling organisations in unstable } \\
\text { environments }\end{array}$ \\
\hline $\begin{array}{l}\text { Sinkula et al. } \\
(1997)\end{array}$ & $\begin{array}{l}\text { Survey - } 125 \text { (managers at } \\
\text { different levels) }\end{array}$ & $\begin{array}{l}\text { Second-order construct with } 3 \\
\text { dimensions: commitment to learning, } \\
\text { shared vision and open-mindedness }\end{array}$ & $\begin{array}{l}\text { Organisational learning is positively related to } \\
\text { performance. }\end{array}$ & $\begin{array}{l}\text { To examine how organisational learning } \\
\text { should be applied and to test the mechanisms } \\
\text { that can implement learning outcomes. }\end{array}$ \\
\hline
\end{tabular}


Table 2: Firm Characteristics

\begin{tabular}{|c|c|c|}
\hline Key characteristics & Range & $\%$ \\
\hline \multicolumn{3}{|c|}{ Firm size (number of employees) } \\
\hline & Less than 10 & 19.80 \\
\hline & $10-50$ & 46.80 \\
\hline & $51-249$ & 22.40 \\
\hline & More than 250 & 11.00 \\
\hline \multicolumn{3}{|l|}{ Firm age (Years) } \\
\hline & Less than 3 & 3.70 \\
\hline & $3-10$ & 39.70 \\
\hline & $11-25$ & 49.20 \\
\hline & $26-50$ & 5.80 \\
\hline & More than 50 & 1.60 \\
\hline \multicolumn{3}{|l|}{ Years of exporting } \\
\hline & Less than 3 & 5.79 \\
\hline & $3-10$ & 50.00 \\
\hline & $11-25$ & 40.08 \\
\hline & $26-50$ & 2.89 \\
\hline & More than 50 & 1.24 \\
\hline \multicolumn{3}{|c|}{ Number of foreign markets } \\
\hline & Less than 3 & 9.92 \\
\hline & $3-10$ & 45.86 \\
\hline & $11-25$ & 34.30 \\
\hline & $26-50$ & 2.48 \\
\hline & More than 50 & 7.44 \\
\hline \multicolumn{3}{|l|}{ Annual export sales $^{\mathrm{A}}$} \\
\hline & Less than 25 & 6.20 \\
\hline & $25-50$ & 40.90 \\
\hline & $51-75$ & 32.30 \\
\hline & $76-100$ & 18.10 \\
\hline & More than 100 & 2.50 \\
\hline \multicolumn{3}{|l|}{ Export region } \\
\hline & Western Europe (including Scandinavia) & 50.41 \\
\hline & Russia and Baltic countries & 22.31 \\
\hline & Eastern Europe & 40.08 \\
\hline & Africa & 82.64 \\
\hline & North America & 54.96 \\
\hline & South and Central America & 41.32 \\
\hline & Middle East & 36.78 \\
\hline & Asia & 45.87 \\
\hline & Australia and New Zealand & 28.10 \\
\hline \multicolumn{3}{|l|}{ Sector } \\
\hline & Manufactured goods \& equipment & 53.30 \\
\hline & Petroleum \& Chemical products & 26.86 \\
\hline & Minerals \& raw materials & 4.13 \\
\hline & Agricultural products & 13.23 \\
\hline & Other & 2.48 \\
\hline
\end{tabular}


Construct and details of measures

Export Learning Orientation Please indicate the extent to which you agree or disagree with the following statements in your export operations $(1=$ strongly disagree, $7=$ strongly agree), adapted from Baker and Sinkula (1999); Gnizy et al., (2014).

Our basic values include learning as a key to improvement

The collective wisdom in this enterprise is that once we quit learning we endanger our future

There is a well-expressed vision of who we are and where we are going as an enterprise

We place a high value on open-mindedness

Marketing Programme Planning Please indicate the extent to which each statement characterizes your firm ( $1=$ strongly disagree, $7=$ strongly agree $)$, adapted from Conant and White (1999).

This firm places a priority on developing written marketing plans

When developing marketing plans, we prepare a written document that serves as a guide for making operational marketing decisions

Our marketing planning procedures are very formal

We understand the strengths and weaknesses of our marketing programme(s)

We have a clear sense of our marketing programme's distinctive competencies and key weaknesses

Psychic Distance Please indicate the degree to which you perceive that your home country to be different from or similar to your firm's most important export market $(1=$ very similar, 7= very different), adapted from Murray et al., (2011); Sousa and Lages (2011).

Preferences of export customers

Culture of export customers

Language of export customers

Customs and values of export customers

Lifestyle of export customers

Export Performance Please evaluate the overall export performance of your firm over the past year relative to your major competitors $(1=$ much worse, $7=$ much better $)$, adapted from Hult et al., (2008), Morgan et al., (2004).

Cash flow from export operations

Export sales growth

Export profitability

Return on assets (ROA)

Export profit growth

Firm Size, number of full-time employees.

International Experience, number of years the firm has been exporting.

Firm age, number of years the firm has been existed.

Industry, industry type of the firm

Export sales, annual export sales of the firm
Standardised Factor Loading

$(t$-value)

$.79(13.55)$

$.80(13.62)$

$.64(10.26)$

$.60(9.60)$

$.89(17.05)$

$.86(16.40)$

$.80(14.70)$

$.74(13.15)$

$.75(13.21)$

$.85(15.79)$

$.81(14.91)$

.85 (15.84)

$.72(12.39)$

$.80(14.61)$

$.80(14.64)$

$.81(14.92)$

$.83(15.45)$

$.82(14.95)$

.97 (20.55)

$.91(18.23)$

$.91(17.98)$

.77 (13.03)

$.75(12.40)$

Fit indices: $\chi^{2}=587.59 ; \mathrm{df}=221, p<.001 ; \mathrm{NFI}=.93, \mathrm{NNFI}=.95 ; \mathrm{CFI}=.96 ; \mathrm{RMSEA}=0.08$ 
Table 4: Descriptive Statistics, Correlations and Validity

\begin{tabular}{|c|c|c|c|c|c|c|c|c|c|}
\hline & 1 & 2 & 3 & 4 & 5 & 6 & 7 & 8 & 9 \\
\hline \multicolumn{10}{|l|}{ 1. Export learning orientation } \\
\hline 2. Marketing programme planning & .59 & & & & & & & & \\
\hline 3. Psychic distance & .43 & .33 & & & & & & & \\
\hline 4. Export performance & .41 & .39 & .35 & & & & & & \\
\hline 5. Firm size $\mathrm{s}^{\mathrm{A}}$ & -.09 & -.04 & -.24 & .01 & & & & & \\
\hline 6. International experience ${ }^{\mathrm{A}}$ & .09 & .19 & .02 & .17 & .13 & & & & \\
\hline 7. Firm age ${ }^{\mathrm{A}}$ & .10 & .15 & .03 & .20 & .11 & .87 & & & \\
\hline 8. Industry type ${ }^{B}$ & -.10 & -.05 & -.05 & -.04 & .01 & .19 & .13 & & \\
\hline 9. Export sales ${ }^{\mathrm{A}}$ & .18 & .09 & .05 & .22 & -.11 & .25 & .18 & .06 & \\
\hline Mean & 5.32 & 5.42 & 5.34 & 5.34 & 3.41 & 2.20 & 2.41 & 1.58 & 3.94 \\
\hline Standard Deviation & 1.02 & 1.01 & 1.20 & 1.05 & 1.25 & .77 & .73 & .49 & .48 \\
\hline Cronbach's Alpha $(\alpha)$ & .80 & .89 & .88 & .91 & - & - & - & - & - \\
\hline Composite Reliability (CR) & .80 & .89 & .89 & .91 & - & - & - & - & - \\
\hline Average Variance Extracted (AVE) & .51 & .64 & .64 & .66 & - & - & - & - & - \\
\hline
\end{tabular}

Correlations above .13 are significant at $p<.05$;

$A=$ Natural logarithm transformation of the original values

$\mathrm{B}=$ Dummy variable 
Table 5: Results of alternative model comparisons

\begin{tabular}{lccccccc}
\hline Models & $\boldsymbol{\chi}^{\mathbf{2}}$ & $\boldsymbol{d} \boldsymbol{f}$ & $\boldsymbol{\Delta} \boldsymbol{\chi}^{\mathbf{2}}$ & $\boldsymbol{\Delta} \boldsymbol{d} \boldsymbol{f}$ & $\mathbf{N F I}$ & CFI & RMSEA \\
\hline Baseline model & 807.05 & 273 & - & - & .94 & .95 & .09 \\
Model 1 & 810.21 & 274 & 3.16 & 1 & .94 & .95 & .09 \\
Model 2 & 831.75 & 275 & $24.7^{*}$ & 2 & .94 & .95 & .09 \\
Model 3 & 815.36 & 275 & $8.31^{*}$ & 2 & .94 & .95 & .09 \\
Model 4 & 804.13 & 272 & 2.92 & 1 & .95 & .96 & .09 \\
Model 5 & 820.92 & 273 & $16.79 *$ & 1 & .94 & .95 & .10 \\
Model 6 & 820.97 & 274 & $16.86^{*}$ & 2 & .94 & .95 & .10 \\
Model 7 & 823.84 & 276 & $19.71^{*}$ & 4 & .94 & .95 & .10 \\
\hline
\end{tabular}

$* p<0.05$
Baseline model: Full mediation model with no direct path from export learning orientation to export performance.

Model 1: the path for Hypothesis 1 was constrained to zero (i.e., the path from export learning orientation to export performance was forced to take the value of zero). For model identification purposes, export learning orientation $\times$ Psychic distance was also forced to zero.

Model 2: the path for Hypothesis 2 was constrained to zero (i.e., the path from export learning orientation to marketing programme planning was forced to take the value of zero). For model identification purposes, marketing programme planning $\times$ Psychic distance was also forced to zero.

Model 3: the paths for moderation model (Hypothesis $3 a$ and $3 b$ ) were constrained to zero (i.e., the paths from export learning orientation $\times$ Psychic distance and marketing programme planning $\times$ Psychic distance to export performance were forced to take the value of zero).

Model 4: A partial mediation model estimated (i.e., the baseline model plus direct paths from export learning orientation to export performance).

Model 5: Direct effect model, direct paths from export learning orientation, marketing programme planning, and moderations only.

Model 6: Non-mediation model, path linking marketing programme planning to export performance constrained to zero.

Model 7: Reverse causality model, marketing programme planning to export learning orientation to export performance.

${ }^{a}$ This is the model with the best fit to the data against which Model 5 to Model 7 are compared. 


\begin{tabular}{|c|c|c|c|}
\hline \multirow[b]{2}{*}{ Hypotheses } & \multirow[b]{2}{*}{ Independent Variables } & \multicolumn{2}{|c|}{ Standardised Parameter Estimates and $t$-values* } \\
\hline & & $\begin{array}{l}\text { Marketing Programme } \\
\text { Planning }\end{array}$ & Export Performance \\
\hline H1 & Export Learning Orientation & $.63(6.70)^{* *}$ & $.18(1.76) \dagger$ \\
\hline $\mathrm{H} 2$ & $\begin{array}{l}\text { Marketing Programme Planning } \\
\text { Export Learning Orientation } \times\end{array}$ & - & $.18(2.00)^{*}$ \\
\hline $\mathrm{H} 3 \mathrm{a}$ & $\begin{array}{l}\text { Psychic Distance } \\
\text { Marketing Programme planning } \times\end{array}$ & - & $-.14(-2.40)^{*}$ \\
\hline \multirow[t]{7}{*}{$\mathrm{H} 3 \mathrm{~b}$} & Psychic Distance & - & $.22(3.73)^{* *}$ \\
\hline & Firm size & $.02(.38)$ & $.10(1.62)$ \\
\hline & International experience & $-.30(-1.43)$ & $.27(1.29)$ \\
\hline & Firm age & $.43(1.97)^{*}$ & $-.18(-.93)$ \\
\hline & Industry type & $.03(.38)$ & $-.08(-1.07)$ \\
\hline & Export sales & $.01(.03)$ & $.19(2.17)^{*}$ \\
\hline & Psychic Distance & $.05(.62)$ & $.25(3.26)^{* *}$ \\
\hline \multicolumn{2}{|c|}{ Total Variance Explained (i.e., $R^{2}$ ) } & $44 \%$ & $37 \%$ \\
\hline \multicolumn{4}{|c|}{ Fit Statistics: $\chi^{2}=804.13 ; \mathrm{df}=272 ; \mathrm{RMSEA}=.09 ; \mathrm{NFI}=.94 ; \mathrm{NNFI}=.95 ; \mathrm{CFI}=.96$} \\
\hline
\end{tabular}

Critical values of the $t$ distribution for $\alpha=0.10, \alpha=0.05$, and $\alpha=0.01$ (two-tailed test) are $\dagger=1.65, *=1.96$, and $* *=2.58$, respectively 